\title{
Mapping of Urban Texture on Interest Heritage Buildings in Semarang
}

\author{
Bambang Adji Murtomo *), Edy Darmawan, Dea Shamara \\ *) Departemen Arsitektur, Fakultas Teknik, Universitas Diponegoro, \\ Jl. Prof. Soedarto, SH, Kampus Undip Tembalang, Semarang, Indonesia 50275
}

\begin{abstract}
Abstrak
Semarang memiliki fasilitas umum yang pantas untuk dikunjungi turis, baik dari dalam negeri maupun dari luar negeri. Permasalahan yang terjadi adalah banyak turis dari dalam dan luar negeri yang hanya lewat begitu saja tanpa transit sama sekali di Kota Semarang. Banyak fasilitas pelayanan umum yang ada dan menarik perhatian. Apabila bangunan religius, bangunan kuno, bangunan kantor pelayanan, bangunan akomodasi, bangunan terminal transportasi baik udara, laut, dan darat. Disamping bangunan, terdapat juga universitas-universitas yang cukup dikenal baik dalam negeri maupun luar negeri. Ruang-ruang terbuka yang cukup menarik. Disamping bangunan converence yang cukup memadai. Perlu publikasi Kota Semarang yang lebih jelas, jaringan yang diperlukan bagi dunia luar maupun masyarakat dalam negeri. Web dan urban texture sangat dibutuhkan bagi Kota Semarang. Oleh karena itu, perlu identifikasi fasilitas umum yang ada di Kota Semarang. Penelitian fasilitas tersebut kemudian menjadi suatu web atau jaringan yang dapat dibaca oleh semua kalangan masyarakat. Dalam penelitian ini dibutuhkan penelitian kualitatif dan kemudian menjadi bentuk web yang menarik serta lengkap bagi Kota Semarang. Hal ini diharapkan akan lebih menarik bagi turis sehingga turis lebih tertarik untuk transit di Kota Semarang.

Keywords: mapping, urban texture, heritage buildings
\end{abstract}

\section{Latar Belakang}

Bangunan bersejarah yang menarik di Semarang cukup banyak jumlahnya. Hal ini dapat dijadikan point bagi turis domestik atau mancanegara untuk dikunjungi. Bangunan Lawang Sewu merupakan icon Kota Semarang yang terletak di kompleks Tugu Muda di Jl. Pemuda, Semarang yang menyatu dengan Taman Tugu Muda yang merupakan simbol Kota Semarang yang telah berubah menjadi taman aktif yang banyak dikunjungi oleh muda-mudi. Dulu taman ini merupakan taman pasif, orang tidak boleh memasuki komplek taman. Disamping tidak boleh mengambil gambar (foto) bangunan sekitar karena masih berfungsi sebagai komplek tentara atau militer. Sekarang Lawang Sewu telah banyak direnovasi dan menjadi kunjungan bagi masyarakat dengan dipungut biaya. Hal ini dikarenakan ruang terbuka aktif dapat digunakan untuk aktivitas, seperti bermain, olahraga, upacara, rekreasi, jalan-jalan, dan berkomunikasi dengan yang lain (Hakim, 2003).

Stasiun Tawang milik PT KAI merupakan peninggalan Pemerintah Belanda yang terletak di Kawasan Kota Lama atau Jl. Taman Tawang No. 1 Semarang. Stasiun Tawang masih menjadi perhatian bagi Pemerintah Belanda untuk dilestarikan. Hal ini

\footnotetext{
${ }^{*}$ Correspondent author

E-mail: bambangadjim@arsitektur.undip.ac.id
}

terbukti masih serius diselenggarakan pelatihan bagi masyarakat Indonesia dengan tema tentang Kota Lama. Disamping itu, bangunan kuno Gereja Blenduk yang terletak di Jl. Letjend. Suprapto termasuk di kawasan Kota Lama merupakan bangunan yang masih berfungsi bagi umatnya untuk mengadakan Misa. Gedung Marabunta yang berdekatan dengan Stasiun Tawang merupakan gedung kuno milik PT EMKL Pada gedung ini terdapat aula yang kondisinya sudah rusak, dan hanya bangunan kantornya yang bisa dimanfaatkan. Di dekat Gereja Blenduk terdapat Gedung Marba yang masih terlihat bagus.

Pasar Johar merupakan peninggalan arsitek Belanda yang bernama Thomas Karsten yang saat ini telah terbakar habis. Beruntung bangunan utama dengan kolom berbentuk jamur masih tersisa. Pasar Johar hampir menutupi Jl. H. Agus Salim karena dipenuhi oleh pedagang kaki lima yang ikut terbakar. Kantor Pos Besar Semarang yang terletak di Jl. Pemuda No. 4 merupakan bangunan kuno yang masih berfungsi sebagai kantor pos dengan bentuk bangunan yang masih utuh. Pemberian warna cat pada dinding bangunannya membuat bangunan Kantor Pos ini terlihat semakin menarik dan interior yang dirubah dengan baik. Halaman depan dipadati PKL dan transit bagi kendaraan angkutan yang lalu lalang memadati halaman parkir depan. Bangunan ini termasuk yang harus dilestarikan sesuai SK Wali Kota Semarang. Toko Oen yang juga 
terletak di Jl. Pemuda No. 52 Semarang merupakan bangunan restaurant kuno yang termasuk harus dilestarikan sampai sekarang. Bangunan Jakarta Lloyd yang termasuk di kawasan Kota Lama Jl. Empu Tantular No. 23 Semarang. Bangunan ini perlu dilestarikan.

Stasiun Poncol telah banyak melakukan renovasi, tetapi bangunan ini juga termasuk dalam bangunan yang perlu dilestarikan sampai sekarang. Stasiun ini masih berfungsi sebagai stasiun dengan kelas ekonomi yang masih ramai dengan penumpang. Stasiun Poncol terletak di Jl. Imam Bonjol, Semarang Utara. Gereja Gereformeered yang terletak di Jl. Sutomo No. 24 Semarang merupakan gereja dengan bentuk yang masih utuh. Bangunan ini cukup menarik dan termasuk bangunan yang harus dilestarikan. Gedung Kesenian Sobokarti yang dulu sangat berperan untuk acara-acara kesenian bagi masyarakat yang terletak di Jl. Dr. Cipto No. 31-33 Semarang. Sekarang, bangunan ini sudah mengalami banyak renovasi.

Hampir di seluruh dunia memiliki China Town, demikian juga dengan Kota Semarang. Klenteng yang merupakan pusat kegiatan bagi komunitas China menjadi pusat kegiatan permukiman China. Bangunan perumahan China memiliki karakteristik yang menarik dan perlu dilestarikan. Demikian pula, klenteng-klenteng yang ada di kuburan China. Meskipun telah banyak renovasi, tetapi bentuk dan karakteristiknya masih hampir sama.

\section{Kajian literatur \\ Bangunan bersejarah sebagai warisan budaya yang memiliki daya tarik wisata}

Bangunan bersejarah di Indonesia sebagian besar merupakan bangunan peninggalan dari masa penjajahan yang berlangsung cukup lama. Bangunan-bangunan tersebut kemudian menjadi cagar budaya yang dilindungi oleh pemerintah dalam Undang-undang No. 11 Tahun 2010 tentang Cagar Budaya. Salah satu isi dari Undang-undang No. 11 Tahun 2010 tentang Cagar Budaya menjelaskan bahwa bangunan cagar budaya diartikan sebagai susunan binaan yang terbuat dari benda alam atau benda buatan manusia untuk memenuhi kebutuhan ruang berdinding dan/ atau tidak berdinding, dan beratap.

Menurut Waterson dalam Hayati (2014), bangunan-bangunan bersejarah tersebut mencerminkan kombinasi antara kekayaan keanekaragaman arsitektur dengan bentang keindahan alam dan keunikan tradisi budayanya sebagai ekspresi budaya yang hidup di dalamnya. Hal inilah yang membuat bangunan bersejarah memiliki daya tarik sebagai wisata budaya.

Joedodibroto dalam Hayati (2014) menyatakan bahwa pemanfaatan bangunan bersejarah erat kaitannya dengan konservasi atau pelestarian bangunan bersejarah. Hal ini dapat diartikan bahwa pelestarian terhadap bangunan bersejarah merupakan tindakan yang penting untuk dilakukan karena melalui pelestarian tersebut banyak manfaat, baik dari sisi ekonomi, lingkungan, dan sosial.

Mansur (2006) menyatakan bahwa dalam mengkaji kegiatan pelestarian bangunan bersejarah membutuhkan kerjasama dari berbagai pihak serta berkelanjutan, dimana salah satu upaya yang dapat dilakukan dengan merubah suatu asset masa lalu menjadi fungsi baru. Upaya ini tidak hanya untuk mengawetkan kawasan bersejarah, tetapi juga bertujuan untuk memberikan kualitas kehidupan masyarakat yang lebih baik, menghasilkan keuntungan dan peningkatan pendapatan, serta tetap memelihara identitas dan sumber daya lingkungan.

Salah satu upaya kegiatan pelestarian bangunan bersejarah adalah melalui konservasi. Tujuan konservasi menurut Burra Charter (ICOMOS atau International Council of Monuments and Site) dalam Tonapa (2015) adalah mempertahankan, memperbaiki, atau memperlihatkan sebanyak mungkin jejak sejarah pada suatu objek bersejarah. Shirvani (1985) mengatakan bahwa konservasi harus memproteksi keberadaan lingkungan dan ruang kota yang merupakan tempat bangunan atau kawasan bersejarah dan juga aktivitasnya. Konservasi menekankan pada penggunaan kembali bangunan lama agar tidak terlantar, baik dengan menghidupkan kembali fungsi lama, maupun dengan mengubah fungsi bangunan lama dengan fungsi baru yang dibutuhkan tanpa mengubah keasliannya serta dapat memberikan nilai ekonomi atau manfaat lain bagi pemilik atau bagi masyarakat luas. Tidak hanya itu, aspek kultural juga harus diperhatikan, sehingga perlu disempurnakan tentang aesthetic, historic, scientific or social value for pust, persent or future generations (Mulyandari, 2010).

Bangunan bersejarah merupakan warisan budaya yang apabila dikembangkan dapat membantu dalam melindungi harta kekayaan alam, budaya bangsa, dan meningkatkan kualitas hidup masyarakat serta pengunjung dalam waktu yang bersamaan. Nuryanti (2009) mengatakan bahwa warisan budaya dalam perkembangannya dipandang sebagai bagian penting dari tradisi kebudayaan suatu masyarakat. Dallen (2003) juga menyatakan bahwa warisan budaya tidak saja masa lalu tapi juga masa kini yang memiliki elemen masa lalu. Dengan demikian, konsep warisan budaya sebagai daya tarik wisata merupakan objek-objek yang berkaitan dengan masa lalu. Daya tarik wisata tidak hanya bergantung pada keindahan alam atau keunikan bangunan saja, tetapi juga dibutuhkan pengelolaan yang baik agar wisatawan tidak merasa bosan ketika berkunjung ke tempat wisata tersebut. Oleh karena itu, pembangunan daya tarik wisata harus dirancang dengan bersumber pada potensi daya tarik yang dimiliki objek 
tersebut dengan mengacu pada kriteria keberhasilan pengembangan (Suwatoro dalam Hayati, 2014).

\section{Spatial Linkage In The Urban Space Theory}

Maki (2002) berpendapat bahwa linkage merupakan perekat suatu kota dan menyatukan semua lapisan aktivitas sehingga menghasilkan bentuk fisik dalam kota. Linkage membawa keluar konsep integrasi, karena menyediakan fakta-fakta yang relevan mengenai lingkungan, dan memungkinkan kita untuk memiliki banyak pengalaman yang disadari atau tidak disadari serta menghubungkan perasaan kita terhadap memori yang terpasang pada ruang melalui waktu dan sejarah. Persepsi ini menggambarkan suasana tertentu sebagai pengakuan untuk fragmen kota dan terpadunya ruang kota. Dengan menganalisis tempat dan hubungan yang kompleks antara bagian-bagian penyusunannya, kita dapat belajar untuk mengenali dan menciptakan kualitas lingkungan perkotaan.

Teori linkage adalah mengenai ruang linear yang menghubungkan satu elemen dengan elemen lainnya. Ini dapat berupa jalan, jalur pejalan kaki, ruang terbuka linear, atau elemen penghubung yang secara fisik menghubungkan bagian-bagian kota. Dengan mengaplikasikan teori linkage, kita dapat menjelaskan urutan ruang dalam kota dan membangun koridor yang menghubungkan landmark dalam kota. Selanjutnya, kita dapat mengatur perintah yang jelas untuk struktur kota berdasarkan koridor yang menghubungkan. Pada penelitian ini, penggunaan teori linkage digunakan untuk menghubungkan fasilitas-fasilitas umum yang termasuk dalam bangunan bersejarah dan berpotensi untuk dijadikan sebagai objek wisata.

\section{Metode penelitian}

Metode penelitian yang digunakan untuk mencapai tujuan penelitian adalah metode penelitian kualitatif. Metode ini dipilih karena dapat menggambarkan dan menjabarkan temuan di lapangan yang bertujuan untuk mengumpulkan informasi secara aktual dan terperinci, mengidentifikasi masalah, membuat perbandingan atau evaluasi, dan menentukan apa yang dilakukan orang lain dalam menghadapi masalah yang sama dan belajar dari pengalaman mereka untuk menetapkan rencana dan keputusan pada waktu yang akan datang (Arikunto, 2006). Hasil akhir metode ini adalah deskripsi detail dari topik yang diteliti (deskriptif).

Observasi atau pengamatan dimaksudkan membuat catatan dari seluruh keadaan dan kegiatan yang diamati, utamanya hal-hal yang berlaku umum bagi masyarakat atau kelompok sasaran serta kondisi lingkungan yang diamati. Dalam laporan ini observasi dilakukan untuk mengamati kondisi bangunan-bangunan bersejarah yang ada di Kota Semarang. Melalui pendekatan penelitian kualitatif, peneliti akan menggambarkan dan menjelaskan keunikan dari bangunan-bangunan bersejarah di Kota Semarang yang berpotensi sebagai daya tarik wisata. Setelah itu, dengan bantuan google map akan dicari lokasi dari masingmasing bangunan bersejarah tersebut. Lokasi bangunan bersejarah yang telah diketahui kemudian disusun membentuk suatu pemetaan agar mudah diketahui oleh masyarakat.

\section{Hasil dan Pembahasan \\ Gambaran Lokasi Penelitian}

Wilayah studi berada di bagian utara Kota Semarang yang dipertimbangkan sebagai kawasan yang kaya akan nilai sejarahnya seperti yang terlihat pada $\mathrm{Gb}$. 19. Kawasan ini tentunya memiliki kegiatan sosial aktivitas yang spesifik dan struktur kota dari berbagai akar budaya yang menampilkan landmark kota. Pada kawasan ini terasa sekali atmosfer suasana Eropa yang ditunjukkan dari bangunan-bangunannya yang bergaya Kolonial Belanda. Kawasan ini memiliki hubungan yang kuat dengan node penting dan tempat-tempat di Kota Semarang, seperti yang terlihat pada Gb. 20. Di sisi selatan, terhubung dengan Simpang Lima yang tumbuh sebagai pusat bisnis dan memiliki karakter yang kuat sebagai pusat kota. Di bagian barat daya, terhubung dengan Tugu Muda yang tumbuh sebagai pusat dengan fungsi campuran, yaitu bisnis, komersial, kantor, pendidikan, museum dan seni. Di sebelah timur, terhubung dengan Jl. Mataram dan Jl. Dr. Cipto yang masih terasa suasana seperti di Kampung Pecinan yang ditunjukkan dengan karakter dominan ruko dan di dekatnya terhubung dengan permukiman warga. Di bagian selatan, terhubung dengan pelabuhan.

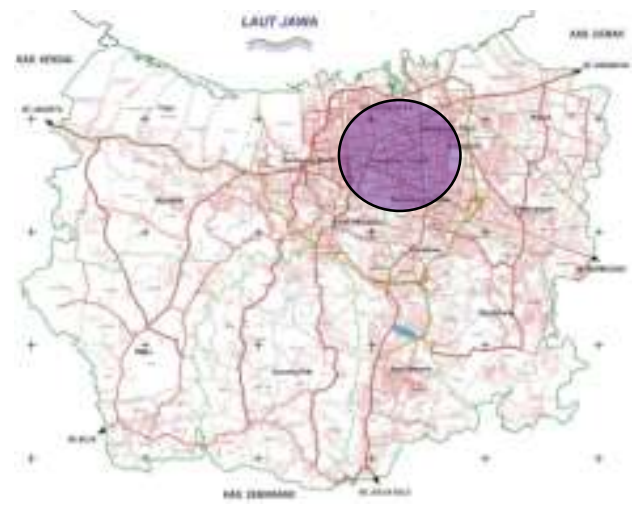

Gambar 1. Lokasi studi 


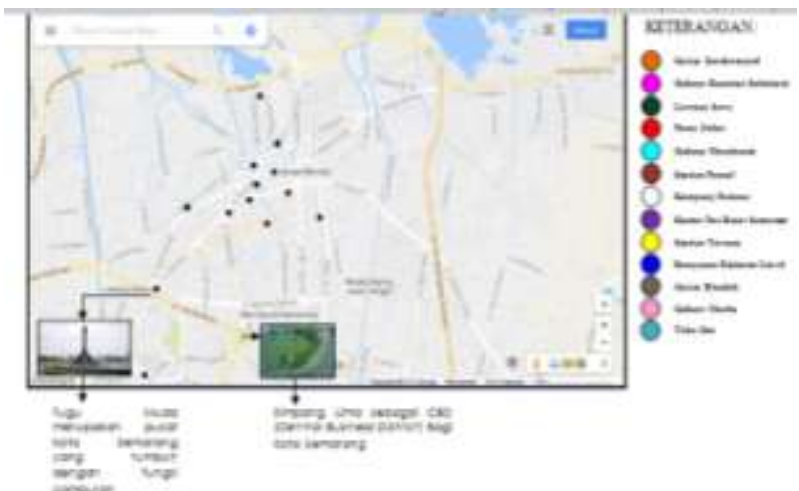

\section{Gambar 2. Lokasi Studi Berada di Nodes dan Tempat-tempat Penting di Kota Semarang}

\section{Analisis}

Kota Semarang memiliki berbagai macam fasilitas-fasilitas umum yang pantas dikunjungi oleh turis. Fasilitas-fasilitas tersebut dapat berupa bangunan keagamaan, bangunan kuno, bangunan kantor pelayanan, bangunan akomodasi, dan bangunan terminal transportasi, serta ruang-ruang terbuka. Keberadaan fasilitas-fasilitas umum tersebut menyebar di beberapa tempat. Untuk menghubungkan fasilitas-fasilitas tersebut diperlukan elemen penghubung yaitu elemen linkage dari suatu kawasan ke kawasan yang lain agar dapat membantu orang untuk mengerti keberadaannya serta untuk mengetahui bagian kota yang merupakan bagian dari keseluruhan bagian yang lebih besar. Linkage merupakan sesuatu yang dianggap penting karena dengan melihat hubungan tersebut maka kawasan-kawasan kota bisa dipahami sebagai sebuah hirarki yang lebih besar daripada hirarki yang ada di dalamnya saja. Teori linkage dapat dipahami dari dinamika rupa perkotaan yang dianggap sebagai generator dari sebuah kota. Analisis linkage adalah alat yang baik untuk memperhatikan dan menegaskan hubungan-hubungan dan gerakan-gerakan dari sebuah tata ruang perkotaan (Zahnd, 1999). Dalam penelitian ini, analisis linkage digunakan untuk menegaskan hubungan fasilitas-fasilitas umum yang termasuk dalam bangunan bersejarah dan memiliki potensi untuk dijadikan sebagai objek wisata.

Wilayah studi berada pada disekitar nodes penting dan tempat-tempat di Kota Semarang dihubungkan dengan jalan-jalan utama dan beberapa jalan sekunder yang dilalui oleh angkutan umum, seperti yang terlihat pada Gb. 21. Sementara jalan-jalan lainnya hanya memberikan gerakan lokal. Hubungan antar jalan membuat wilayah studi mudah untuk diakses dari banyak bagian kota. Di tingkat mikro, terlihat jelas bahwa jalan utama dan jalan-jalan sekunder melalui wilayah studi. Namun pada jalan-jalan sekunder, terdapat beberapa bagian yang tidak memberikan kualitas ruang yang baik bagi pejalan kaki dan pengendara sepeda. Area ini hanya dapat dilalui oleh sepeda motor saja, sehingga pergerakan menjadi terbatas. Hal ini perlu mendapat perhatian khusus baik dari pemerintah maupun masyarakat, karena daya tarik wisata yang dimiliki oleh suatu objek wisata tidak hanya bergantung pada keindahan alam atau keunikan bangunannya saja, tetapi juga dibutuhkan pengelolaan yang baik agar wisatawan tidak merasa bosan ketika berkunjung ke tempat wisata tersebut.

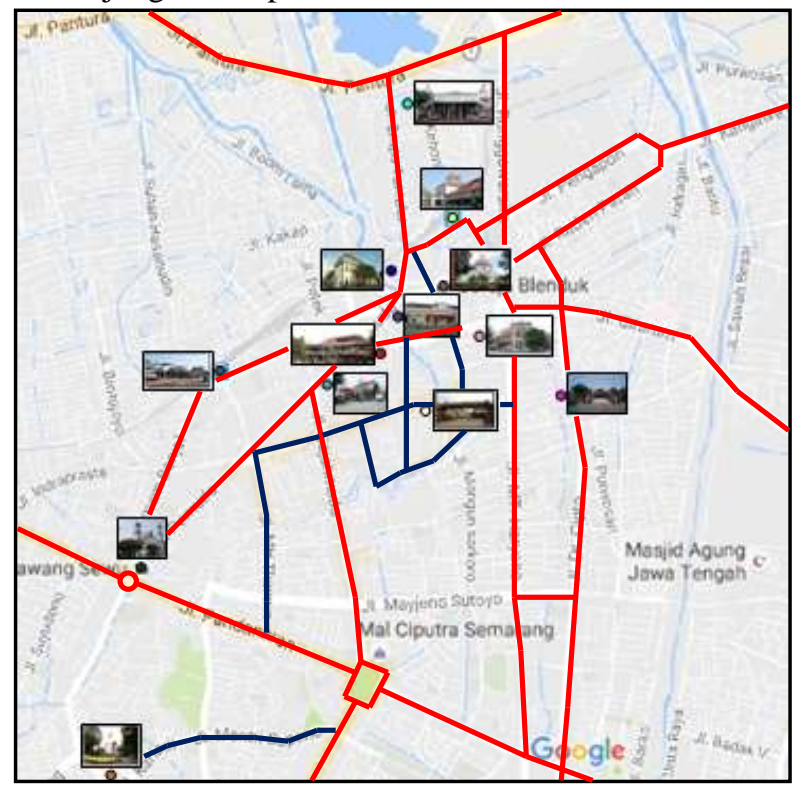

Gambar.3 Lokasi studi dilalui oleh jalan utama dan sekunder

Sebagaimana yang dikatakan oleh Suwatoro dalam Hayati (2014) yaitu pembangunan daya tarik wisata harus dirancang dengan bersumber pada potensi daya tarik yang dimiliki objek tersebut dengan mengacu pada kriteria keberhasilan pengembangan, maka sebaiknya fasilitas-fasilitas umum yang memiliki nilai sejarah ini didukung dengan fasilitas yang dapat mendukung pemanfaatan fasilitas-fasilitas umum untuk objek wisata. Salah satunya dengan mempertimbangkan kondisi jalan yang dapat diakses oleh pejalan kaki dan pengguna sepeda, karena berjalan kaki dan bersepeda tidak tergantung pada arah. Selain itu, perlu adanya pengembangan pada transportasi darat lokal agar wisatawan dalam negeri maupun luar negeri dapat dengan mudah mengunjungi wilayah studi.

\section{Kesimpulan}

Dari hasil kajian dan pembahasan yang telah disampaikan sebelumnya dapat diambil kesimpulan bahwa:

1. Kota Semarang memiliki fasilitas-fasilitas umum yang bernilai sejarah tinggi dan berpotensi untuk dikembangkan menjadi objek wisata yang dapat 
dinikmati oleh wisatawan. Fasilitas-fasilitas umum tersebut berupa bangunan-bangunan bersejarah peninggalan Pemerintah Kolonial Belanda.

2. Lokasi fasilitas-fasilitas umum mudah dijangkau karena berada di jalan utama dan jalan-jalan sekunder, serta dilalui oleh angkutan umum dan kendaraan pribadi. Meskipun demikian, fasilitasfasilitas umum tersebut kurang diminati wisatawan.

3. Beberapa bagian jalan-jalan tidak memberikan kualitas ruang yang baik bagi pejalan kaki dan pengendara sepeda. Area ini hanya dapat dilalui oleh sepeda motor saja, sehingga membuat pergerakan menjadi terbatas.

4. Untuk itu, perlu adanya penyediaan kualitas ruang untuk pejalan kaki dan pengendara sepeda serta pengembangan transportasi darat lokal untuk memberikan kenyamanan bagi wisatawan ketika berkunjung ke wilayah studi.

\section{Daftar Pustaka}

Arikunto, 2006. Prosedur Penelitian: Suatu Pendekatan Praktik. Jakarta: PT Rineka Cipta

Dallen, J. Timothy and Stephen W. Boyd. 2003. Heritage Tourism "Themes in Tourism". USA: Prentice Hall Publisher.

Hakim, Rustam, dan Hardi Utomo. 2003. Komponen Perancangan Arsitektur Lansekap (Prinsip-Unsur dan Aplikasi Desain). Jakarta : Penerbit Bumi Aksara.

Hayati, Rafika. 2014. Pemanfaatan Bangunan Bersejarah Sebagai Wisata Warisan Budaya di Kota Makassar. JUMPA (Jurnal Master Pariwisata). Volume 1 Issue 01 Pages 1-22. Program Studi Magister Kajian Pariwisata Universitas Udayana.

Maki, Fumihiko. 2002. Investigation Into Collective Form: Seminar on Linkage Theory of Urban Design About The Work of Maki. Cambridge University. USA.

Mansur, F. 2006. Konservasi dan Revitalisasi Bangunan Lama di Lingkungan Kota Donggala. Jurnal Mektek (Media Komunikasi Teknologi). Edisi Mei 2006. Universitas Tadulako Palu.

Mulyandari, Hestin. 2010. Pengantar Arsitektur Kota. Yogyakarta: Penerbit ANDI.

Nuryanti, Wiendu. 2009. Sinergi Arsitektur dan Pariwisata Dalam Membangun Indonesia Kreatif. Pidato Pengukuhan Jabatan Guru Besar Pada Fakultas Teknik Universitas Gadjah Mada.

Shirvani. Hamid. 1985. The Urban Design Process. New York: Van Nostrand Reinhold Company.

Tonapa, Yenie Naftalia. 2015. Kajian Konservasi Bangunan Kuno dan Kawasan Bersejarah di Pusat Kota Lama Manado. Program Studi
Perencanaan Wilayah dan Kota. Universitas Sam Ratulangi Manado. www.ejournal.unsrat.ac.id Undang-undang Nomor 11 Tahun 2010 tentang Cagar Budaya.

Zahnd, Markus. 1999. Perancangan Kota Secara Terpadu. Yogyakarta: Kanisius. 